\title{
The Social Dilemma of Tin Mining of Non-miners People : A Comparative Study Between Bangka and Belitung People's Perception
}

\author{
Ibrahim $^{1 *}$, Dwi Haryadi ${ }^{2}$, and Nanang Wahyudin ${ }^{3}$ \\ ${ }^{1}$ Department of Political Science, Faculty of Social and Political Sciences, Bangka Belitung University, Bangka - \\ Indonesia \\ ${ }^{2}$ Department of Law, Faculty of Law, Bangka Belitung University, Bangka - Indonesia \\ ${ }^{3}$ Department of Management, Faculty of Economic, Bangka Belitung University, Bangka - Indonesia
}

\begin{abstract}
Tin mining has been massively occurred in Bangka Belitung Islands Province. It has already happened since the last 20 years which was started by retraction of tin status as state strategic commodity. This condition has caused the dilemma among the local people and stakeholders in this region as its positive and negative impact walks side by side. This study described how the knowledge, attitude, and expectation of a large community, especially for those who are not miners. Generally, local people understand that this region is rich for its tin and in fact it's already given a big contribution foreconomic development. Local people also admit that the benefit on tin mining is only enjoyed by some people. Nevertheless, local community also has an attitude that in-conventional mining has already damaged the environment and they hope it will be prohibited. Local people have expectation that environmental management should be prioritized and strictly limited to the tin mining activity. This study founded that there is a gap perception between Bangka and Belitung People although they are in the same level of agreement related to the expectation to prohibit the tin mining : Belitung people is higher than Bangka people.
\end{abstract}

Keywords: Dilemma, Tin, Inconventional Mining, Perception

\section{Introduction}

Tin mining in the Bangka Belitung Islands has been going on for hundreds of years, but the mining chronicles have accumulated over the last two decades. Tin mining is suddenly present as the most discussed commodity in various social spaces. Politically, tin has a very high impact because mine opening policies involve political processes at the elite level and at the same time engage the wider community as miners. Meanwhile, economically, tin mining is becoming a new livelihood sector for people in the grassroots. Apparently not only that, since tin released its status as a commodity regulated and supervised by the central government, tin into new business fields. At least this has been the case since 1998, a condition in which Indonesia is entering the fall of Suharto and begins to wriggle the era of reform and regional autonomy. At least to this day, data show that the Bangka Belitung economy is still sustained by the mining sector.

What actual mining is going on in the area with the world's second largest tin reserve? $[1,2,3]$. This is called the chron of tin mining. Tin mining in hundreds of years has indeed been mined by a large company called Banka Tin Winning and continued by PT. Lead. However, the local community has only had the opportunity to mine precisely since its status as a strategic commodity of the country is revoked. This authority is actually contained in Local Regulation no. 6 of 2001, however, the regulative status of vacuum over the condition of tin management has actually occurred since 1998.

The last 20 years are the years filled with stories about illegal mining of lead in the packaging of the Inconventional Mine name. The last 20 years is also a year marked by mining in any place, environmental damage, socio-cultural damage, and loss of state property that actually happens just as the country is preparing to enter the industrial age [4]. Instead of supporting the commitment of low carbon development, the environment damage as an impact of mining even trigger the opposite condition. The last 20 years have been characterized by a non-civilized local context, between mining legalized by the government

* Corresponding author: iim_babel@yahoo.com 
and serving as an arena of capital accumulation by the international capitalist and tin players [see 5].

Then how exactly the position of people in this area? The complicated social dilemma occured meaning that there is conflict between individual expectation and many people's interest. Although tin mining creates a multiplier effect, it can not be negated that the struggle for tin resources is more characterized by the contradiction between idealism to safeguard tin natural wealth and capitalist aggression and short-term lust. Tin is slowly fading although at this time tin is still a prima donna in this area. Long before tin can be directly mined by the community, the livelihoods of the people in this area have relied on the plantation sector with its global pepper and rubber, as well as the potential of fisheries that have sustained the economic life of the community. There is an interesting question, how exactly is the public perception of tin mining activity in this area?

Recently, the wave of rejections against mining has been going on. Various communities and community groups in their own way to fight against the expansion of tin mining. Apparently, behind the less productive tin mining by small-scale engine power, the aggression of large-scale miners such as suction vessels remains unstoppable. Behind the persistence of tin mining, there are conditions where tin is rejected by non-miners. It is actually interesting to observe the various movements of rejection of the entry of mining in this area because it is characterized by prolonged clashes and conflicts.

The fishermen community is a relatively large group doing the movement of rejection of tin. In addition to the diminishing revenue and fishing areas, the wave of rejection by fishermen is also supported by a desire to safeguard their nature from massive environmental damage. Meanwhile, real resistance also emerged from various social groups, especially in unspoiled areas.

The author sees the interesting phenomenon that the resistance to tin mining actually departs from various bad perceptions about the impact of tin mining. Belitung Island people tend to assume that the damage that occurred on the island of Bangka not to spread to their area. Not surprisingly, the rejection of mining activities on these two islands is relatively different.

This paper will elaborate on how actually people's views on these two islands have been on massive tin mining activities since 1998. Non-miners are important for their perceptions because they assume they live together in this archipelago as a spectator of the tin mining lead actually determine themselves and their future. Although not directly bound by the mining context, but the activities of the people are not miners actually can not be separated directly. Approximately, the authors assume that the people who are not miners actually have the perception and expectation of the mining itself. As audiences, nonmining communities are tied and directly related to the tin mining dilemma. This paper intends to observe: after the tin mining story that happened in front of the eyes, how they then put the tin mining now.

\section{Research Methodology}

This paper is obtained from the results of quantitative research using questionnaires to obtain research data. The question is arranged in the form of Likert scale with descriptive approach which measure three big variables, namely knowledge of context, attitude, and expectation to tin mining. SPSS 20 data analysis technique is used to analyze the data of questionnaire results. The data retrieval technique is done with non-probablity sampling system using quota sampling with special characteristic is public society which do not work as a miner and not as policy maker. This study measures how the public perceptions to find out how exactly their perceptions of tin mining are familiar in their daily lives, whether the respondents are connected directly or not to the mining world. Respondents are spread across all districts / municipalities in the province of Bangka Belitung Islands with a total of 210 respondents, each detailing the quota of 30 people per district / city.

\section{Finding and Discussion \\ 3.1 Respondent's Identity Non-Miners}

The respondents surveyed are fairly evenly distributed across each age range so that the differences between age ranges are not much different, most at 29$38,39-48$, ie $27.1 \%$ and $26.2 \%$, while the lowest i.e. in the age range $19-28 \%$. Respondents in this study is more dominated by male gender that is equal to $79 \%$. Sampling conducted by non-probability sampling allows gender not to be an important consideration in the mapping of non-miners' perceptions of society.

The largest number of respondents is the original / local population, which amounted to $92.4 \%$. The local population in this case is defined as those who have ID cards in the province of Bangka Belitung Islands Province. The mapping of these population characteristics explains that this study mostly takes a sample of the community that exists and is active in the province.

Educational groups that get a larger portion, namely high school graduates $34.8 \%$ and University $24.3 \%$. This condition generally reflects the educational conditions of people who do not work as miners. Most respondents work in the informal sector, which is $56.2 \%$. As for the formal and non-working jobs amounted to $21.9 \%$ each. Formal work is defined as those who work in a fixed agency.

\subsection{Knowledge of Context}

\subsubsection{Knowing clearly that Bangka Belitung is rich with its tin}

$51 \%$ of respondents answered strongly agree, and $45.2 \%$ agreed. This means that $96.2 \%$ of respondents agree that they know about the wealth of Bangka Belitung will be tin. This data explains that respondents are aware of the potential of tin contained in their area. 


\subsubsection{Knowing that tin contribution to the economy in Bangka Belitung is high}

$53.3 \%$ of respondents agree and $20.5 \%$ strongly agree on the question that they know and agree with the very high contribution of tin to the economic community in this province. This condition explains that in the understanding of the respondents, tin does have a very big influence on the economy of the people of Bangka Belitung.

\subsubsection{Knowing the miners do outlaw}

$52.9 \%$ of respondents agreed and $37.1 \%$ strongly agreed. This means that $90 \%$ of respondents know that many tin miners are indeed violating the rules or unlicensed. This data indicates the fact that it is commonly understood that mining does not obey rules and violate permits.

\subsubsection{Knowing that the mining is forbidden unconventionally}

$46.2 \%$ of respondents agree and $36.2 \%$ strongly agree that indicates that the majority of respondents know about the prohibition to tin mining unconventional. That is, that the general public already knows that it is unconventional mining is prohibited. However, this knowledge has no impact on the movement of rejection of tin mining due to the fact that mining is still active. It is interesting because of the fact that there is an awareness that conventional tin mining, but not automatically makes people who are not miners to take concrete actions to stop. There is a kind of apathetic condition pertaining to the two data above.

\subsection{Attitude}

\subsubsection{Attitude about Neglecting the Mining}

$44.8 \%$ of respondents strongly agree and $23.8 \%$ strongly agree if unconventional mining seems left alone. That is, there is general awareness in the mining community that there is no firm step in curbing tin mining in this region. This seems to be relevant also to the question of the understanding of the prohibition of incommunicable mining, ie the existence of awareness of omission, but not enough basis for forming a denial movement of lead mining as intended.

\subsubsection{Attitude about Outlaw Protection to Unconventional Mining}

$44.3 \%$ of respondents agree and $29.5 \%$ strongly agree if this unconventional mining is protected by unscrupulous personnel. That is, the majority of respondents know the operation of unconventional mining due to the protection provided by unscrupulous to the miners of the conventional [compare with the study 6].

\subsubsection{Attitude as awareness of environmental damage} is massive because of tin mining

$48.6 \%$ of respondents agree and $44.8 \%$ strongly agree if it says massive environmental damage occurs as a result of tin mining. Almost all mining communities believe that tin mining has damaged the environment. This confirms the findings of many parties that tin mining has significantly impacted a large socio-environmental impact [see eg 7, 8, 9, 10, 11]). It is the same with some questions that awareness and understanding of the negative processes of tin mining and its impact, but the various rejection movements do not automatically arise. The tendency that can be interpreted in the end is the tendency of apathy toward the condition that it is perceived differently.

\subsubsection{Attitude that the Environmental Damage has not resolved by the government}

$54.3 \%$ of respondents agree and $32.4 \%$ strongly agree with the attitude that environmental damage has not been well addressed by the government. The majority of the public are aware and stated that the environmental damage has not been addressed properly. Of course this seems to depart from the daily lives of people who are dealing directly with damaged environmental conditions.

\subsubsection{Attitude that mining is profitable for minority}

$47.1 \%$ of respondents agree and $31.4 \%$ strongly agree if it is said that tin mining basically only benefit a small number of people. The majority of society means realizing that the benefits to the small community from mining are few. This is a unique finding because so far many arguments that actually say that society is very benefited with the current conditions. In fact, the people who responded to this study said that the benefits of this situation were only a small part.

\subsubsection{Attitude that unconventional mining should be banned}

$37.1 \%$ of respondents agree and $30 \%$ strongly agree that unconventional tin mining should be strictly prohibited and actioned. That is, that $67.1 \%$ of respondents want unconventional tin mining should be dealt with firmly. This is interesting considering that so far there is some assumption that the community refuses if the Conventional Mine will be closed considering the consideration is about the income of the community that will be affected directly if there is a firm stance in disciplining the unconventional Mining.

\subsection{Expectation}

3.4 1 Expectation to the urgency (1) regulation (2) law (3) environmental effect maintenance

The highest score is only $23.8 \%$, that is, the expectation of the respondent wants the environmental impact management to be solved first, then then the regulation structuring again and then law enforcement. Furthermore, $20.5 \%$ of respondents hoped to prioritize the enforcement of new law followed by regulation reorganization and environmental impact management, but if the note from the percentage of respondents' answers do not happen disparity of value far, meaning that the three sequences are urgent to do immediately, no matter where the prior sequence should be done.

\subsection{Expectation to the Future (1) Status Quo (2) Limitation}

Respondents answered $72.9 \%$ of the future expectation of tin mining is the limitation of tin, while $27.1 \%$ still want the status quo. There is an interesting condition that although there is an awareness to say tin destroys the environment, impressed left, and other aspects of 
perception, yet there are still about a quarter of nonminers wanting a status quo.

\subsection{Perception between Bangka and Belitung People}

Meanwhile, it is interesting to observe the differences of non-miners' views of society between the Bangka community and the Belitung people. The communities of these two islands are relatively different views and contexts though both are areas with tremendous tin wealth. Tin mining on Bangka Island is more massive compared to the two islands. On the contrary, a wave of rejection of tin mining in Belitung Island is more massive. The following data presents a divergence of views which, although not extreme, can adequately illustrate how these differences reflect perceptions that tend to be parallel.

\subsection{Knowing clearly that Bangka Belitung is indeed rich of tin \\ Meanwhile, it is interesting to observe the differences of non-miners' views of society between the Bangka community and the Belitung people. The communities of these two islands are relatively different views and contexts though both are areas with tremendous tin wealth. Tin mining on Bangka Island is more massive compared to the two islands. On the contrary, a wave of rejection of tin mining in Belitung Island is more massive. The following data presents a divergence of views which, although not extreme, can adequately illustrate how these differences reflect perceptions that tend to be parallel.}

\subsection{Knowing that tin contribution to Bangka Belitung Economy is high}

The contribution of tin is very high on the economy of Bangka Belitung, Belitung respondents answered slightly higher than Bangka respondents, which is 55\% and $52.7 \%$ answered agree to mean that the very high contribution of tin to Bangka Belitung economy is recognized by the community.

3.5.3 Knowing that many miners break the law Respondents acknowledge that many tin miners are breaking the rules. Belitung Island has the highest answer presentation of $58.3 \%$ agreed and Bangka $50.7 \%$ agreed, meaning that the two island respondents acknowledged that tin mining done so far has violated the regulation.

\subsubsection{Knowing that unconventional mining is forbidden}

Belitung Island and Bangka answered agree by $55 \%$ and $42 \%$ so that most respondents have known that unconventional tin mining is prohibited, but there are still $8 \%$ and $11.7 \%$ both Bangka and Belitung there are still respondents who do not know if unconventional tin mining is prohibited.

\subsubsection{Attitude that unconventional mining seemed to be left alone}

Bangka Island respondents stated agree on $45.3 \%$ and Belitung Island is $43.3 \%$ high agree that most respondents both Bangka Island and Belitung respondents considered that the mining of unconventional seemed to be left alone.

\subsubsection{Attitude that unconventional miners are protected by outlaw}

On the question of unconventional protected mining, the respondents of Belitung Island agree the highest, 51.7\% and Bangka $41.3 \%$, mean that it is recognized that unconventional mining practices are protected by persons, but there are $7.3 \%$ on the island of Bangka which states disagree.

\subsubsection{Attitude that Environmental Damage as the Result of Mass tin mining}

Respondents in Bangka Island the highest answered strongly agree $52 \%$ which means the public recognizes the bottom in Bangka Island environmental damages due to tin mining is very massive, whereas in Belitung Island respondents answer the highest agree of $61 \%$ which means Belitung island community also recognize the damage tin environments occur massively.

\subsubsection{Attitude that Environmental Damage has not yet resolved by the government}

Belitung Island states agreement with higher value than Bangka, which is $61.7 \%$ means that the people of Belitung recognize the environmental damage has not been overcome well, so also Bangka Island 51.3\% environmental damage has not been overcome well.

\subsubsection{Attitude that tin mining actually benefits only a small number of people}

The people of Bangka Island and Belitung Island responded predominantly to the agreed option and strongly agreed with the total $84.3 \%$ for Bangka Island and $80 \%$ of Belitung Island, meaning that the community generally acknowledges that tin mining actually benefits only a small number of people.

\subsubsection{Attitude that unconventional miners should be} banned and punished firmly

Respondents of Bangka Island answered agree and strongly agree a total of $61.4 \%$ means that the people of Bangka Island mostly want unconventional tin mining actioned firmly, while Belitung Island has a higher percentage than Bangka Island, which is $81.6 \%$ which means that the people of Belitung island want a firm action against unconventional miners, but so there are still do not want it, that is as many as $14,7 \%$ of respondents answered disagree.

3.5.11 Expectation of urgent lists should be solved (1) Regulation arrangement (2) law enforcement (3) environmental impact management

The three proposed policies proposed, the island of Bangka would prefer a new environmental impact management of another policy, that is $25 \%$ means that it wants to repair the damage of the environment first such as reclamation and so on afterwards the need for regulation of re-regulation and just implemented the action law. But unlike the island of Belitung by $30 \%$ 
want law enforcement, after that regulation and further regulation of environmental impact management.

\subsubsection{Expectation of Future Hope (1) Status Quo (2) Limitation}

$65 \%$ of Bangka respondents preferred restrictions, but lower than Belitung at $86.7 \%$, which means that most people want a restriction rather than a status quo option. This seems to depart from the fact that environmental degradation is massive and the fact that the perception of tin mining is only believed to provide greater benefits to a small number of people [12].

\section{Conclusion}

The study concluded that there is social dilemma for respondents, namely as the awareness and understanding will confront the wider and more obvious interest. Most of the respondents acknowledged and understood that Bangka Belitung is indeed rich in tin resources and has a major contribution to the economy of people in this area. Respondents also know that basically a lot of tin mining is breaking the rules and they also generally know if mining is prohibited. The impression that tin mining is left alone is also the answer of the majority of respondents. It is interesting that the understanding of the negatively disqualified conditions over tin mining does not automatically form a movement under the contextual conditions. Perceptions and actions are not linear in terms of positioning unconventional tin mining.

At the level of attitude, most respondents agree and strongly agree if it is said that tin mining is much protected by the authorities. In the same attitude it was also revealed that most of the respondents agreed and strongly agreed that there was massive damage to the environment and the impression that the environmental damage had not been adequately addressed by the government. Interestingly, most respondents also say that tin mining benefits only a small proportion of people. At the attitude level too, most respondents agreed that unconventional tin mining was firmly acted upon.

At the expectation level, respondents want that environmental damage is urgent to be addressed first, then followed by regulatory arrangement, and then law enforcement. The majority of respondents also wanted a restriction on tin mining activity rather than the choice of status quo.

Meanwhile, at the level of perception comparison between the people of Bangka Belitung, a fairly high disparity there is a level of attitude so that unconventional tin mining should be banned and dealt with firmly. Respondents in Bangka Island stated higher approval, which is $81.6 \%$, while in Belitung Island is $61.4 \%$

This study ultimately concludes that the community is stuck in a dilemma in positioning unconventional tin mining in the Bangka Belitung Islands Province. On the one hand, this study shows that the general public actually perceives negative mining activities either regarding the prohibition of mining, broadcasting, to the perception of environmental damage, including actual expectations to crack down and ban unconventional mining explicitly. It means, there is awareness from society to encourage the prevention of environmental damage related to the low carbon development. On the other hand, movements or actions that lead to the rejection of tin mining are very limited. That is, between perception and action is not linear.

Thanks to Directorate of Higher Education for supporting this research by Research Competence Grant.

\section{References}

[1] Supriadi, Agus, et.al, Analisis Pembentukan Harga di Bursa Timah Indonesia dan Dunia, Pusat Data dan Teknologi Informasi Energi dan Sumber Daya Mineral, Kementerian Energi dan Sumber Daya Mineral, Jakarta (2016).

[2] Sujitno, Sutedjo, Dampak Kehadiran Timah Indonesia Sepanjang Sejarah, Cempaka Publishing, Jakarta (2015).

[3] Erman, Erwiza, Jurnal Masyarakat Indonesia, Aktor, Akses dan Politik Lingkungan di Pertambangan Timah Bangka, Edisi XXVI, No. 2, pp. 71-101 (2010).

[4] Ibrahim, et.al., PEOPLE : International Journal of Social Sciences, From Charm to Sorrow (The Dark Portrait of Tin Mining in Bangka Belitung, Indonesia), Volume 4, Issue 1, pp. 360-382 (2017).

[5] Irawan, R. Rudy, et.al., International Journal of Business and Management Review, Strategic Model of Tin Mining Industry in Indonesia (Case Study of Bangka Belitung Province) Volume 2, No. 3, pp. 48-58 (2014).

[6] Haryadi, Dwi, Jurnal Masalah-Masalah Hukum, Faktor Kriminogen Ilegal Mining Timah di Bangka Belitung Volume 44, No. 1, pp. 52-58 (2015).

[7] Febriyanto, Arief, et.al., International Journal of Science : Basic and Applied Research (IJSBAR), The Impact of Tin Mining on Squid (Urotheutis Chinensis) Fishing Ground in South Bangka, Volume 23, No.1, pp. 283-293 (2015).

[8] Muslih, Khairul, et.al., AKUATIK-Jurnal Sumber Daya Perairan, Karakteristik Habitat dan Keanekaragaman Ikan Air Tawar Sungai Menduk yang Mendapat Pengaruh Penambangan Timah di Kabupaten Bangka Habitat Characteristics and Biodiversity of Freshwater Fish in Menduk River that Got Influence Tin Mining in Bangka, Volume 8, No. 2, pp. 17-23 (2014).

[9] Milieudefensie, Responsible Mining Tin, Goodelectronics, Amsterdam (2016).

[10] Stocklin-Weinberg, R., et.al, Occupational Health \& Safety Situational Analysis \& Training Needs Assesment for Unconventional (Artisanal) Miners in Bangka Belitung, Indonesia, Washington, D.C., U.S.: Pact, Final Report (2017).

[11] Yunianto, Bambang, Jurnal Teknologi Mineral dan Batubara, Kajian Problema Pertambangan Timah di Propinsi Kepulauan Bangka Belitung sebagai Masukan Kebijakan Pertimahan Nasional, Volume. 5, No. 3 (2009). 
[12] Susilo, Joko \& Siti Maemunah, Tiga Abad Melayani Dunia, Potret Tambang Timah Bangka Belitung, Jaringan Advokasi Tambang (JATAM), Jakarta (2009). 